

\section{Shirkah}

Journal of Economics and Business

Vol. 3, No. 1, January-April 2018

ISSN: 2503-4235 (p); 2503-4243 (e)

\section{Editor in Chief}

Dwi Condro Triono

\section{Managing Editor}

Jasanta Peranginangin

\section{Editorial Boards}

Abdul Azim Islahi,

Islamic Economics Institute, King Abdulaziz University, Saudi Arabia

Abu Umar Faruq Ahmad,

UBD School of Business and Economics Universiti, Brunei Darussalam

Cedomir Nestorovic,

ESSEC Business School Asia Pacific, Singapore

Fitri Wulandari,

Faculty of Islamic Economics and Business, IAIN Surakarta, Indonesia Johan Fischer,

Department of Social Sciences and Business Roskilde Universitetscenter, Denmark Muhamed Zulkhibri,

Islamic Research and Training Institute, Islamic Development Bank, Saudi Arabia M. Kabir Hassan,

Department of Economics and Finance, University of New Orleans, United States Musa Asy'arie,

Faculty of Islamic Economics and Business, IAIN Surakarta, Indonesia

Nunung Nurul Hidayah,

Aston Business School, Aston University, Birmingham, United Kingdom

Saim Kayadibi,

Department of Economics, Kulliyyah of Economics and Management Science, International Islamic University Malaysia, Malaysia 
Shaikh M Ghazanfar,

Departement of Economics, University of Idaho, Russian Federation

Sigit S. Wibowo,

Department of Management, Faculty of Economics and Business, Universitas Indonesia, Indonesia

Vihang R. Errunza,

Desmarais Global Finance Research Centre, Desautels Faculty and Management, McGill University, Canada

\section{Assistant to Editor}

M. Endy Saputro

M. Zainal Anwar

Shirkah Journal of Economics and Business is a peer-reviewed journal published three times a year (January-April, May-August and September-December) by Faculty of Islamic Economics and Business, Institut Agama Islam Negeri (IAIN) Surakarta Central Java, Indonesia. The main objective of Shirkah is to offer an academic space of exchange ideas and initiate the increase number of qualified article produced by postgraduate students, practitioners and academicians.

\section{Editorial Office}

Ruang Jurnal Shirkah

Lantai Dasar, Sayap Barat, Fakultas Ekonomi dan Bisnis Islam, IAIN Surakarta

Jln. Pandawa No. 1, Kartasura, Sukoharjo, Jawa Tengah Kode Pos. 57168

Phone (+62271) 781516 Fax: (+62271)782336

E-mail: shirkahjournal@iainsurakarta.ac.id; shirkahiainsurakarta@gmail.com

Website: http://shirkah.or.id/ 


\section{Shirkah}

Journal of Economics and Business

Vol. 3, No. 1, January-April 2018

ISSN: 2503-4235 (p); 2503-4243 (e)

\section{Table of Contents}

\section{Articles}

Aqeel Akhtar

Fahad Ahmed Qureshi

Mubeen Butt

Laws of Collateral in Today's World in Islamic Perspective

Anton Bawono

Creative Economic Development of Pesantren

Dwi Umardani

Conventional Home Loan and Islamic Home Financing in

Comparative Perspective

Iha Haryani

Dian Riskarini

Tia Ichwani

Business Development Strategy Model of SMEs

through SWOT and EFE-IFE Analysis

Ika Yoga

Halal Emotional Attachment on Repurchase Intention

Anik

Iin Emy Prastiwi

Macro Economic Challenges and Third Party Funds of Islamic Commercial Banks in Indonesia 


\title{
Business Development Strategy Model of SMEs Through SWOT and EFE-IFE Analysis
}

\author{
Iha Haryani \\ Faculty of Economics and Business Universitas Pancasila \\ Iha.haryani@yahoo.com \\ Dian Riskarini \\ Faculty of Economics and Business, Universitas Pancasila \\ dian.riskarini@gmail.com \\ Tia Ichwani \\ Faculty of Economics and Business, Universitas Pancasila \\ tia.ichwani@gmail.com
}

\begin{abstract}
Considering that the SME entrepreneurs of Gresik Regency are mostly young, educated and experienced, however their businesses are not yet in legal entities. This research situates the SME business development strategy model through SWOT and EFE-EFI analysis, aiming to identify the conditions and models of SME business development strategies to improve their performances. This research has interviewed 40 respondents who were selected in multi stage, and analyzed through SWOT and EFE-IFE analysis. The result of this research explains that the ability of SME entrepreneurs in managing business and the achievement level of marketing performance is good, except the ability to manage finances. In addition, external conditions support these SMEs.
\end{abstract}

Keywords : SWOT, EFE-IFE, business development strategy, SMEs

\section{Introduction}

Gresik Regency is one of the regencies in East Java, Indonesia with a large number of SMEs engaged in marine fish processing businesses. This type of business includes processing fresh fish, salting/drying, salting 
and seasoning, smoking, and such processed products as shrimp paste, crackers, and petis. However, these SMEs face some problems, including: lack of innovation, lack of capital, inability to apply adequate technology and information, lack of management and marketing skills, and the spread of the location. To optimize the utilization of marine fishery products and make this sector the prime mover of economic development, this article shows that SMEs are a tool of national struggle to grow and develop the economics by involving as many potential economic practitioners as possible based on justice for all stakeholders (Wilantara, 2016). Therefore, this SME development requires the right strategy as an acceleration and breakthrough effort for the SME development supported by political and economic policies and appropriate social climate.

The business development strategy is the creation of longterm value for consumers and markets related to the task and analytical preparation process for the potential opportunities growth and assistance to the implementation process of opportunity growth, but it does not include decision making, formulation, and direct implementation of opportunities growth (Sancoko, 2015). Tools for developing business development strategies include SWOT and EFE-IFE analysis. Such previous studies on SWOT and EFE-IFE analysis for business development strategies as of Helms \& Nixon's (2010) explains that SWOT analysis can analyze organizations and can provide recommendations for strategic activities; the results of the study (Chan, 2011), SWOT assists the business in developing feasible strategies, and simultaneously provides an in-depth understanding of the "global" strategy of the future as one of the most successful enterprises in China; study results (Abubakar \& Bello, 2013), applying SWOT analysis in the Nigerian Mobile Telecommunication Industry, among the findings are that Globacom is the second in terms of market share (subscriber base) and having the most advanced network 
(technology), fast, robust and cheap excess bandwidth from GLO-1, being financially strong and the most innovative telecom operator in Nigeria constitutes its competitive advantage.

Other studies of (Muhammad, Adeel, Ayub, 2013) argues that the impact of pre-job evaluation in assessing SWOT analysis appears to be positive for effective strategic marketing planning. The results of Joko's study, et al (2015), through EFE-IFE analysis, the position of Rumah Tempe Indonesia in the second quadrant is growing and building. Following these studies, yet in different manners, it is necessary to conduct a study on business development strategy models of SMEs through SWOT, EFE and IFE analysis. The objective of this study is to determine the conditions and models of SME business development strategies of marine fish processing in Gresik Regency, East Java. Indonesia has the opportunity to produce the world's largest marine fishery products due to the vastness of the sea it has and contribution of marine fisheries from year to year has increased (Osita, Christian Ifediora.; Onyebuchi R, 2014). Opportunities to develop marine products and fisheries businesses in Indonesia have good prospects to boost the economy of the community particularly SMEs (Small and Medium-Scale Enterprises) (Abubakar \& Bello, 2013).

\section{Quantitative Studies of SMEs}

This article is a quantitative study describing the condition of SMEs. The population of this study is the SME entrepreneurs of marine fish processing in Gresik Regency, East Java. The sample used 40 selected multi-stage SMEs. Four (4) villages that have many (purposive) SMEs of marine fish processing were determined in phase one as sample units, namely Ujung Pangkah Village of Ujung Pangkah District, Kramat Village of Duduk Sampeyan District, Mengare Village and Indrodelik Village of Bungah District. In the second phase, 10 entrepreneurs of the SMES from each village were randomly selected as respondents. 
The measuring instrument in this study is a questionnaire consisting of statements with alternative answers on a Likert scale, namely the value of 1 (disagree), 2 (neither agree nor disagree/neutral), and 3 (agree). The level of SMEs condition on this study is expressed based on the calculation (the highest value - the lowest value)/the highest value, namely $(3-1) / 2=$ 0.67. So that the level of the condition values are: $1.00-1.67=$ low, 1.68 $-2.34=$ medium, and $2.35-3.00=$ high .

Variable of strengths is a special competition that provides a competitive advantage for companies in the market including natural resources owned, skills, or other advantages related to company competitors and market needs that can be served by companies that are expected to be served (Bloomsbury.com, n.d.). Weaknesses are limitations or shortcomings in natural resources, skills, and capabilities that effectively inhibit the company's performance, including facilities, finance, management skills, and marketing skills (Osita, Christian Ifediora; Onyebuchi R, 2014). Opportunities are important situations that benefit the company environment, such as technological changes and the improved relationship between companies and buyers or suppliers give a picture of opportunities for the company (Abubakar \& Bello, 2013). Threats are important situations that are not favorable in the corporate environment. The existence of new or revised government regulations can be a threat to the success of the company (Fajar, 2016).

Data is analyzed by SWOT. SWOT analysis method has been widely used as a tool for planning and analyzing strategic actions over the past decade (Ramavanavar, Gomesh M.; Charantimath, 2012). SWOT is an acronym of strength, weakness, opportunities, and threats (Oreski, 2012). SWOT is a system or process of considering the internal and external factors affecting the performance of an organization in relation to competitor or market situation (Abubakar, Nura.; Bella, 2013). Strengths 
and weaknesses are internal to the entity under evaluation whereas opportunities and threats refer to the broad context or environment in which the entity operates (Kreiner, Collins, Wall, 2007).

This external factor evaluation (EFE) influences the formation of opportunities and threats (Rangkuti, 2016), whereas these factors are related to conditions that occur outside the company that affect the company's decision making. External factors include economic strength, social, cultural, demographic and environmental strength, political power of government and law, technological strength, and competitive strength (Purwono, Suryaningsih, Putri, 2015; Abubakar, Bella, 2013). In doing so, before a strategy is implemented, strategic planning must analyze the external environment (Kassim, Redzuan, Harun, 2017). Internal factor evaluation (IFE) influences the formation of strengths and weaknesses. Whereas these factors are related to the conditions that occur in the company, which also influence the formation of company's decision making. Internal factors include management, marketing, human resources (HR), finance/accounting, production/operations etc (Purwono, Suryaningsih, Putri, 2015).

The tool used to develop a business development strategy is a SWOT matrix consisting of EFE analysis based on opportunities and obstacles and IFE based on strengths and weaknesses (Rangkuti, 2016). There are 4 alternative business development strategies based on SWOT analysis, namely: S-O Strategy. This strategy has very favorable conditions, i.e. the system has good strengths and opportunities. The SO strategy is developed based on the company's mindset, namely by taking advantage as much as possible all the strengths and opportunities. The system of $S-T$ Strategy has strengths but faces various threats. This strategy is developed using the company's strengths to overcome threats. The system of W-O strategy has good opportunities, but is constrained by internal weaknesses (Niinimäki, 2018). 
This strategy is implemented by minimizing existing weaknesses and utilizing opportunities. The right strategy is to minimize internal problems, so that they can seize external opportunities better (Chan, 2011). The W - T Strategy has very unfavorable conditions. This strategy is based on activities that are defensive and try to minimize existing weaknesses and avoid threats. See Table 1.

Table 1. SWOT Matrix

\begin{tabular}{|c|c|c|}
\hline EFE & Strength $(\mathrm{S})$ & Weakness $(\mathrm{W})$ \\
\hline Opportunity $(\mathrm{O})$ & S - O STRATEGI & W - O STRAGEGY \\
\hline Obstacle $(\mathrm{T})$ & S - T STRATEGY & W - T STRATEGY \\
\hline
\end{tabular}

The strategies that can be implemented based on SWOT conditions (Nur, 2013), are as follows: S-O strategy is to maintain and improve product quality and after-sales service, develop a middle to lower market, and hold exhibition activities; W-O strategy is a targeted promotion, more vigorous promotion by holding, following, or as a sponsor in various events, promotion through printed media, and social networking media, and increasing the sales network (Razak \& Taib, 2011) debt-based financing, and diminishing partnership (DP; S-T strategy is to develop competitiveness and improve good relations with customers (Rafay \& Farid, 2017). The W-T strategy is to expand the promotion area by opening outlets to expand the sales network, adding variety of dealer sales such as selling trendy motorcycle accessories in the community, giving price discounts to loyal customers. 


\section{Respondents and Condition of SMEs}

Male respondents are the same as women. Most (67.5\%) are young ( $\leq 40$ years). Most (67.5\%) have high school education and above. Most (95\%) are not legal entities. Most SMEs produce fish crackers. Others produce shrimp paste, petis, nugget, etc. The condition of SMEs in Gresik Regency is good in terms of the ability of SMEs in the management of employees, production, marketing strategies and performance, but the financial management skill of the SMEs is moderate. Meanwhile the external conditions of SMEs are able to provide support to the business development. This fact is indicated by the index level in the management of employees, production, external, marketing strategies and performance i.e. $\geq 2.34$, except for the index of financial management activities i.e. $\leq$ 2.34.

Table 2. Business Management Levels and External Conditions of SMEs

\begin{tabular}{|l|c|}
\hline & Mean \\
\hline Employees & 2.36 \\
\hline Production & 2.49 \\
\hline Finance & 2.33 \\
\hline External Business & 2.59 \\
\hline Marketing Strategy & 2.52 \\
\hline $\begin{array}{l}\text { Marketing } \\
\text { Performance }\end{array}$ & 2.80 \\
\hline
\end{tabular}

Source: The results of data processing

The results of previous studies shows that SWOT analysis helped one of the two studied to advance in the face of growing challenges leading to its stability and increased productivity (Osita and Onyebuchi, 2014); SWOT model of thirukkural is a complete analysis of any problems that an entrepreneur may have to face while starting a new business (Jain, 2015). 
In this article, the strengths of these SMEs are employee recruitment planning carried out in accordance with the needs of the work unit (S1), carrying out the recruitment process, selection, placement, orientation, and introduction to get employees who fit the needs (S2), assigning clear tasks to employees in writing and its implementation (S3), organizing in such a way that employees work in a coordinated manner within a work unit or between work units (S4), carrying out employee development activities that can improve technical skills and behavior to support the achievement of business goals ( 55 ), supervision of work of employees by business owners or managers (S6), sanctions given to employees for disciplinary violations (S7) and ease of obtaining suppliers with raw materials that meet the business needs (S8).

Following it, other work units contains machines/equipment used for the production process (S9), the work steps for the production process so that the finished product quality is guaranteed (Rusby, 2016) (S10), the supply of raw materials and finished goods are stored in a safe place and avoiding the risk of damage/expiration (S11), planning of income and financial expenses and profits (S12), knowing the calculation of working capital costs needed for a production process (S13), determine the price and profit of an item (S14), the separation between assets and owner's debt with the business unit's assets and debt (S15), the product already has a variety of tastes that consumers like (S16), the product has a variety of packaging and size (S17), products are made with special attention to the quality of raw materials (S18) (Kashif, Abdur Rehman, \& Pileliene, 2016), products are made with special attention to the health of consumers (S19), the product has a variety of affordable prices for consumers (S20), offering clear prices on goods price list (S21), the product is sold in a place that is easily accessible by consumers (S22) (Amin, 2017), facilities for the convenience of consumers to transact such as goods delivered, purchases 
via telephone, online, etc (Razak \& Taib, 2011). (S23), promotional activities are carried out periodically to introduce products both through WA, brochures, signboards, etc. (S24).

The weaknesses of SMEs are that the monthly wages/salaries are not in accordance with government regulations (UMP) (W1) (Ahmad \& Burki, 2016), there are no incentives other than wages/salaries (W2), there are no other rewards besides salaries (W3), there is no health or old age insurance such as BPJS, etc. (W4), inadequate inventory of raw materials (W5), every business transaction in this business has not been processed by a computer (W6), the document regarding the recording of each business activity transaction from this business is inadequate (W7), owners or financial managers rarely evaluate the finance and financial systems of businesses (W8), owners or financial managers rarely check business finances (W9), there are no offers of several promos such as discount promos, free of charge promos (bonuses), and gift promos (W10), this product does not have a registered trademark (W11).

The opportunities that these SMEs have are increasing market share compared to the previous year $(\mathrm{O} 1)$, profit growth compared to the previous year $(\mathrm{O} 2)$, sales volume growth compared to the previous year (O3), and increasing customer satisfaction compared to the previous year (O4). Meanwhile the challenges that the SMEs must face are facing a high level of business competition (T1), the natural situation greatly influences production activities (T2), has a relatively high level of buyer bargaining power (T3), has a relatively high level of supplier bargaining power (T4), there is no support from BUMN/BUMD for increasing this business (T5), and there is no support from other parties (T6).

Based on Tables 2 and 3, the results show that the IFE score $=$ 3.00, greater than the EFE score $=2.606$. This means that these SMEs prioritize internal factors rather than external factors. Strength score $=$ 
2.429 is greater than the weakness score $=0.571$. Obstacle score $=1.336$ is greater than the opportunity score $=1,270$.

Table 3. IFE Analysis

\begin{tabular}{|c|c|c|c|c|}
\hline No & Statement Item & $\begin{array}{l}\text { Weight } \\
\text { (W) }\end{array}$ & $\begin{array}{l}\text { Rating } \\
\text { (R) }\end{array}$ & WxR \\
\hline & Strength: & & & \\
\hline 1 & S1 & 0.026 & 2.40 & 0.062 \\
\hline 2 & S2 & 0.035 & 2.65 & 0.093 \\
\hline 3 & S3 & 0.021 & 2.40 & 0.050 \\
\hline 4 & S4 & 0.032 & 2.68 & 0.086 \\
\hline 5 & S5 & 0.037 & 2.78 & 0.103 \\
\hline 6 & S6 & 0.028 & 2.45 & 0.069 \\
\hline 7 & S7 & 0.027 & 2.48 & 0.067 \\
\hline 8 & S8 & 0.025 & 2.50 & 0.062 \\
\hline 9 & S9 & 0.025 & 2.38 & 0.059 \\
\hline 10 & $S 10$ & 0.027 & 2.58 & 0.070 \\
\hline 11 & S11 & 0.032 & 2.65 & 0.085 \\
\hline 12 & S12 & 0.025 & 2.53 & 0.063 \\
\hline 13 & S13 & 0.025 & 2.50 & 0.063 \\
\hline 14 & S14 & 0.028 & 2.55 & 0.071 \\
\hline 15 & S15 & 0.024 & 2.43 & 0.058 \\
\hline 16 & S16 & 0.038 & 2.75 & 0.104 \\
\hline 17 & S17 & 0.038 & 2.78 & 0.106 \\
\hline 18 & S18 & 0.039 & 2.75 & 0.107 \\
\hline 19 & S19 & 0.031 & 2.60 & 0.081 \\
\hline 20 & S20 & 0.026 & 2.55 & 0.066 \\
\hline 21 & S21 & 0.027 & 2.60 & 0.070 \\
\hline 22 & S22 & 0.028 & 2.63 & 0.074 \\
\hline 23 & S23 & 0.026 & 2.55 & 0.066 \\
\hline
\end{tabular}




\begin{tabular}{|c|c|c|c|c|}
\hline 24 & S24 & 0.026 & 2.45 & 0.064 \\
\hline & Sub total & 0.696 & & 2.429 \\
\hline & Weakness & & & \\
\hline 1 & W1 & 0.032 & 2.30 & 0.074 \\
\hline 2 & W2 & 0.027 & 1.83 & 0.049 \\
\hline 3 & W3 & 0.027 & 1.83 & 0.049 \\
\hline 4 & W4 & 0.025 & 1.85 & 0.046 \\
\hline 5 & W5 & 0.027 & 1.68 & 0.045 \\
\hline 6 & W6 & 0.033 & 1.93 & 0.063 \\
\hline 7 & W7 & 0.028 & 1.80 & 0.050 \\
\hline 8 & W8 & 0.024 & 1.78 & 0.042 \\
\hline 9 & W9 & 0.022 & 1.70 & 0.037 \\
\hline 10 & W10 & 0,034 & 2.03 & 0.069 \\
\hline 11 & W11 & 0.025 & 1.90 & 0.047 \\
\hline & Sub total & 0.304 & & 0.571 \\
\hline & Total & 1.000 & & 3.000 \\
\hline
\end{tabular}

Source: the results of data processing

Table 4. EFE Analysis

\begin{tabular}{|l|l|c|c|c|}
\hline No & Statement Item & $\begin{array}{c}\text { Weight } \\
(\mathrm{W})\end{array}$ & Rating (R) & WxR \\
\hline & Opportunity & & & \\
\hline 5 & O5 & 0.111 & 2.68 & 0.297 \\
\hline 6 & O6 & 0.111 & 2.80 & $0-311$ \\
\hline 7 & O7 & 0.114 & 2.85 & 0.325 \\
\hline 8 & O8 & 0.117 & 2.88 & 0.337 \\
\hline & Sub total & & & 1.270 \\
\hline & Challenges & & & \\
\hline 1 & T1 & 0.091 & 2.63 & 0.239 \\
\hline 2 & T2 & 0.107 & 2.80 & 0.300 \\
\hline
\end{tabular}




\begin{tabular}{|r|l|c|c|c|}
\hline 3 & T3 & 0.084 & 2.65 & 0.223 \\
\hline 4 & T4 & 0.111 & 2.70 & 0.300 \\
\hline 5 & T5 & 0.080 & 1.88 & 0.150 \\
\hline 6 & T6 & 0.074 & 1.68 & 0.124 \\
\hline & & 1.00 & & 1.336 \\
\hline & & & & 2.606 \\
\hline
\end{tabular}

Source: the results of data processing

\section{Business Development Strategy}

Based on the above analysis, it is found that the business development strategy model of this business is the S-T strategy, meaning that these SMEs optimize the strengths they have to overcome the obstacles they face. Therefore, the strategy recommendations for SMEs are to develop competitiveness and improve good relations with customers (Oreski, 2012). The same study explains that the SWOT and EFE/IFE matrix in order to analyze and investigate the implementation and advices of e-Government in Oman using secondary data from statistical reports (Salmi \& Hasnan, 2015; Jain, 2015).

The management implication of this study is that the SME entrepreneurs of marine fish processing in Gresik Regency, East Java need to further optimize the strengths $(S)$ by having a large number of workers who are ready to work. In addition, the suppliers should be easy to get, simple machinery/equipment can be used and there is guaranteed product quality, raw material inventory and finished goods are stored in a safe place and the risk of damage/expiration should be avoided, experienced in calculating working capital costs, prices, and profits (Ahmed, 2010; Yusof, Oseni, \& Hasan, 2016). Furthermore, they must have the skills to administer finances, calculate the cost of working capital, prices, and profits. The product has a variety of tastes, packaging and sizes, and prices (Bian, 
Lin, \& Liu, 2018). They should also provide convenience for consumers to conduct transaction such as delivery of goods, telephone purchases, online, etc(Alhifni, Huda, Anshori, \& Trihantana, 2017). In addition, SMEs need to seek more information about MSME empowerment programs from the central and regional governments, BUMNs, universities and other parties who have an interest in improving the welfare of the community, especially the SME entrepreneurs of marine fish processing in Gresik Regency, East Java. This is needed so that SMEs can face obstacles $(T)$ such as tight business competition, the natural situations that have great influence on production activities, the relatively high bargaining power of buyers, the relatively high bargaining power of suppliers, lack of support from BUMD and from other parties for increasing this business (Carneiro-Da-Cunha, Dos Santos, De Souza, Alssabak, \& Macau, 2015).

The variables of this study are strengths, weaknesses, opportunities, and threats from several aspects including marketing performance, which is one indication that describes the progress of a company or a measure of achievement obtained from the overall marketing activity process of a company (Best, 2009). Ferdinand (2007) explains that good marketing performance is expressed in three main quantities, namely customer growth, sales growth, and market share. According to Kotler and Keller (2009), measurement of marketing performance can be seen from the conformance between the profit level, sales volume, market share, and customer satisfaction. Every business manager is required to make decisions that support the achievement of the company's goals through the earnings, namely the company's net profit; sales volume is goods sold in the form of money for a certain period of time and in it has a good service strategy; customer satisfaction is one's feelings after comparing the performance of the product he feels with his expectations (Abdullah, Kedah, \& Anwar, 2015). According to Ujang et al (2011), market share is the percentage of 
company sales compared to its close competitors, or is a key indicator of market competition because it shows how much the market is controlled by a company against its competitors.

The success of a company is largely determined by the success of the marketing efforts of the products it produces. According to Kotler and Keller (2009), the financial success of a business often depends on its marketing capabilities. Operational, financial, accounting, and other business functions are meaningless when there is no demand for products and services so the company does not make a profit (Ahmed, 2010). In doing so, marketing is an unavoidable aspect and must be carried out by a business engaged in sales or production. According to Halim (2016), marketing is an activity, a set of institutions, and a process for creating, delivering, and proposing a value offer to consumers, clients, partners, and society at large. Conceptually it is known that the four elements that influence the marketing success of a business, namely: product, price, place, and promotion.

According to Kotler and Keller (2000), a product is anything that can be offered to market to satisfy a want or need. Products that are marketed include physical goods, services, experiences, events, persons, places, properties, organizations, information and ideas. According to Lovelock and Wright (2007), products consist of goods, services, experiences, events, people, places, ownership, organization, information, and ideas; prices and other service costs are expenses of money, time, and effort by customers to provide and consume services; place and time are management decisions about when, where, and how to deliver goods and services to customers; promotion and education are all activities and tools that trigger communication designed to build customer preferences for goods and services, as well as providers of certain goods and services (Kashif et al., 2016). 
In addition to good products, good HR (Human Resources) also determines the success of a business. According to Gary (2016), HR management is the process of obtaining, training, assessing, providing compensation to employees, paying attention to their work relationships, health, security and justice issues. According to Edy (2012), human resources are employees who are ready, able, and alert in achieving organizational goals. With better employee performance, even small businesses can provide great results. But to achieve this goal, good and directed HR management is needed for a business so that it can contribute meaningfully to the business. When HR management can be managed properly, business operations can run in balance. According to Edy (2012), there are three functions of $\mathrm{HR}$ management, namely managerial functions (planning, organizing, directing and controlling), operational functions (procurement, development, compensation, integration, maintenance, and termination of employment, and achievement of integrated organizational goals).

The production process is not directly related to consumers. However, obstacles in the production section can result in product/ service being hampered to the consumers, which eventually results in disappointment or a bad image (Abubakar and Bella, 2013). If SMEs are not supported by a good production management system, then it might hamper the sales process which can ultimately harm the producers and can disappoint consumers. According to Sofjan (2016), the production process in a business activity includes the change process from raw materials to finished goods. The elements involved in the production process are raw materials, semi-finished goods, finished goods, machinery, equipment, methods, and others (Maamor, Rahman, \& Hamed, 2016). Some activities in production management that need attention are: purchase of raw materials, quality control, finished goods storage, maintenance and delivery of goods. 
Money is the blood for the survival of all business activities that must be fulfilled to finance a business. Therefore, good management or financial management is needed to achieve the goals of a business (Ali, Mukhtar, \& Sofwan, 2016). According to Kasmir (2016), financial management is related to earnings, funding, and asset management activities with several overall objectives, including how to obtain and manage funds to finance a business so that the company's objectives are achieved, and how the company manages its assets efficiently and effectively. In financial management there are 3 focuses of attention, namely: aspects of funding sources, planning and use of funds, as well as financial supervision/control (Ali et al., 2016). Company funding sources are internal and external spending. The use of internal funds is the easiest way to get because it only takes available funds, including the use of business funds, use of reserves, and the use of profits that are not shared/ retained. But usually the amount is very limited (Fitriati, 2012). External funding sources include funds from owners or investments, loans both short and long term, assistance from central or regional government programs, funds from friends or family who want to invest, venture funds (Abdullah et al., 2015). Meanwhile, there are three aspects that must be considered in designing the use of costs, namely the initial costs or costs required when the company will be established, projections/financial designs that include the daily balance sheet, income statement, and cash flow statements, as well as analysis of capital return. Meanwhile, financial supervision/control is based on verification of financial transaction records in the form of financial statements.

External conditions can be identified through activities that include careful observation of competition, regulation, inflation rate, business cycle, consumer desires and expectations, and other factors that can identify opportunities and threats (Abubakar and Bella, 2013). Companies or SMEs must have strategic planning. Company leaders must try to find 
a balance between internal and external strengths of a market and be able to objectively see internal and external conditions. Strategic planning is important for gaining competitive advantage (Rangkuti, 2003).

\section{Conclusion}

SMEs of marine fish processing in Gresik Regency, East Java will develop. This is because most business entrepreneurs are young, relatively well educated, and experienced. In addition, the skills of SMEs in Gresik Regency in terms of employee management, production, external business, and marketing strategies and the marketing performance achievement are good, except their financial management skill. The management index level of employees, production, external, marketing strategy and performance is $\geq 342.34$, but the index level in the financial management is $\leq 34$ 2.34. The SME entrepreneurs of marine fish processing in Gresik Regency, East Java set their business priority on overcoming internal factors rather than external factors. This business development strategy model is S-T, which means optimizing the strengths in order to minimize obstacles that they must face. Therefore, the strategic recommendation is to develop competitiveness and improve good relations with customers.

This article can be use as an input for the government, universities or other parties that have an interest in the development of SMEs, among others, to provide opportunities for SMEs to participate in training to improve internal business management, namely human resources, marketing, and production; providing opportunities or support for these SMEs to participate in exhibitions that can develop markets for marine fish processing products. This study can be an approach for further study on the influence of internal and external business factors on SME marketing strategies and performance as well as study on the influence of business development strategy factors on SME performance. 


\section{References}

Abdullah, M. A., Kedah, Z., \& Anwar, M. A. (2015). Effects of Islamic entrepreneurship mind programming on entrepreneurial performance through entrepreneurial motivation. International Journal of Business and Globalisation, 15(3), 294-312. https://doi.org/10.1504/ IJBG.2015.071909

Abubakar, N., \& Bello, G. B. (2013). Strengths, Weaknesses, Opportunities and Threats ( Swot) Analysis on Globacom Ltd. International Journal of Information Technology and Business Management, 16(1), 83-91. https://doi.org/10.1300/J156v02n03_05

Ahmad, S., \& Burki, A. A. (2016). Banking deregulation and allocative efficiency in Pakistan. Applied Economics, 48(13), 1182-1196. https:// doi.org/10.1080/00036846.2015.1096001

Ahmed, A. M. E. T. (2010). Islamic banking: How to manage risk and improve profitability. John Wiley \& Sons.

Ali, H., Mukhtar, \& Sofwan. (2016). Work ethos and effectiveness of management transformative leadership boarding school in the Jambi Province. International Journal of Applied Business and Economic Research, 14(11), 7451-7471.

Amin, H. (2017). Consumer behaviour of Islamic home financing: Investigating its determinants from the theory of Islamic consumer behaviour. Humanomics, 33(4), 517-548. https://doi. org/10.1108/H-12-2016-0102

Bian, X., Lin, Z., \& Liu, Y. (2018). House price, loan-to-value ratio and credit risk. Journal of Banking and Finance, 92, 1-12. https://doi. org/10.1016/j.jbankfin.2018.04.006

Bloomsbury.com. (n.d.). Islamic Finance: Instruments and Markets. Retrieved January 18, 2018, from https://www.bloomsbury.com/us/ islamic-finance-instruments-and-markets-9781849300179/ 
Carneiro-Da-Cunha, J. A., Dos Santos, M. G., De Souza, L. J., Alssabak, N. A. M., \& Macau, F. R. (2015). The history of an Islamic entrepreneurship: Achieving exporting-network leadership through religious legitimacy. International Journal of Business and Globalisation, 15(3), 272-293. https://doi.org/10.1504/IJBG.2015.071921

Chan, X. (2011). A SWOT Study of The Development Strategy of Haier Group as One of The Most Successful Chinese Enterprises. International Journal of Business and Social Science 2, 11, 147-153.

Jain, A. (2015). SWOT Analysis in Thirukkural : Comparative Analysis with Humphrey SWOT Matrix. IQSR Journal of Business and Management (IQSR-JBM) 7, 1, 31-34.

Kashif, M., Abdur Rehman, M., \& Pileliene, L. (2016). Customer perceived service quality and loyalty in Islamic banks. TQM Journal, 28(1), 62-78. https://doi.org/10.1108/TQM-01-2014-0006

Kassim, S. H., Redzuan, N. H., \& Harun, N. Z. (2017). What drives house price in Malaysia? In search of an alternative pricing benchmark for islamic home financing. Planning Malaysia, 15(4), 21-34.

Kreiner, Noga Collins., Wall, G. (2007). Evaluating tourism potential : A SWOT analysis of The Wester Negev. Review 55, 1, 51-63.

Maamor, S., Rahman, N. L. A., \& Hamed, A. B. (2016). Determinants of islamic home financing product selection among lower income group in Kuala Lumpur,Malaysia. International Journal of Economics and Financial Issues, 6(7Special Issue), 197-201.

Oreski, D. (2012). Strategy development by using SWOT-AHP. TEM Journal 1, 4, 283-291.

Osita, Christian Ifediora., Onyebuchi R, I. . J. N. (2014). Organizational's stability and productivity: the role of SWOT analysis an acronym for strength, weakness, opportunities, and threat. International Journal of Innovative and Applied Reseach 2, 9, 23-32.

Purwono, Joko, Suryaningsih, Sri., Putri, R. T. (2015). Strategi Pengembangan Bisnis Rumah Tempe Indonesia di Kota Bogor, Propinsi Jawa Barat. Jurnal NeO-Bis 9, 1, 60-71. 
Rafay, A., \& Farid, S. (2017). Dynamic relationship between islamic banking system and real economic activity: Evidence from Pakistan. Journal of King Abdulaziz University, Islamic Economics, 30(2), 97116. https://doi.org/10.4197/Islec.30-2.10

Ramavanavar, Gomesh M.; Charantimath, P. M. (2012). Strategic Formulation Using TOWS Matrix- A Case Study. International Journal of Research and Development 1, 1, 2-9.

Rangkuti, F. (2016). Analisa SWOT: Tehnik Membedah Kasus Bisnis Analisa SWOT. Jakarta: Gramedia Pustaka Utama.

Razak, D. A., \& Taib, F. M. (2011). Consumers' perception on Islamic home financing: Empirical evidences on Bai Bithaman Ajil (BBA) and diminishing partnership (DP) modes of financing in Malaysia. Journal of Islamic Marketing, 2(2), 165-176. https://doi. org/10.1108/17590831111139875

S Muhammad., Iftekhar, Hanan. Adeel., Aslam, Ayub, A., Razza. (2013). No Title. A Conceptual Framework on Evaluating SWOT Analysis As The Mediator in Strategic Marketing Planning Through Marketing Intelligence, 2, 91-98.

Salmi, M. A. A. Al, \& Hasnan, N. B. (2015). SWOT and TOWS matrix e-Government analysis review on Sultanate of Oman. International Journal of Learning \& Development, 5(4), 13-23. https://doi. org/10.5296/ ijld.v5i4.8641

Sancoko, A. H. (2015). Strategi Pengembangan Bisnis Usaha Makanan dan Minuman Pada Depot Time To Eat Surabaya. Agora, 3, 185-194.

Wilantara, R. F. Susilawati. (2016). Strategi \& Kebijakan Pengembangan UMKM. Upaya Meningkatkan Daya Saing UMKM Nasional di Era $M E A$. Bandung: Refika Aditama. 


\section{Shirkah Author Guidelines}

Shirkah currently offers two routes to submit manuscripts. We highly recommend to submit the articles which are made using OJS (Open Journal System). Feel free register as author soon through visiting http:// shirkah.or.id/index.php/home/user/register. The authors may directly send their manuscripts, along with their resume, to shirkahiainsurakarta@ gmail.com. Please prepare your manuscripts, using following guidelines:

1. Manuscript must be written in English. Submitted articles should not have been published or be under review for publication with another journal.

2. Manuscript's length is about $15-20$ pages, typed in one-half spaced on A4-paper size.

3. Manuscript must include an $150-200$ word abstract and keywords.

4. Manuscript must be arranged as follows: Title, Name of Author, E-mail address, Abstract, Keywords, Introduction (including method if any), Discussion, Conclusion, References.

5. Manuscript's titles not more than ten words.

6. Manuscript must be submitted in Microsoft Word or RTF.

7. Arabic words should be transliterated according to the style of International Journal of Middle Eastern Studies.

8. Manuscript references are preferably derived from the up-to-date references.

9. The author's resume should be submitted separately, consisting of at least full name, institutional address, phone number, areas of studies, and recent publications (if any).

10. Shirkab use APA Style 6th edition (2010) as reference format writing. We suggest the use of a reference manager software such as Mendeley, Zotero, and Endnote at templating the citation style. APA Style to be used is as follows: 


\section{Book with single author}

Swann, G. M. Peter. (2014). The Economics of Innovation an Introduction. Cheltenhum \& Northampton: Edward Elgar.

in-text citation: (Swann, 2014)

\section{Articles in reference books}

Alatas, S. F. (2006). Islam and the Science of Economics in Abu Rabi', I.M. The Blackwell Companion to Contemporary Islamic Thought. USA: Willey-Blackwell (pp. 587-606).

in text citation: (Alatas, 2006)

\section{E-Book}

Hackett, Rosalind (2007). "Religous Dimentions of War and Peace: Introduction.” Dalam Gerrie ter Haar dan Yoshio Tsuruoka (Ed.), Religion and Society: An Agenda for the 21st Century (h. 3-6). Retrieved from http:// brill.nl.

in text citation: (Hackett, 2006)

\section{Master's thesis, from a commercial database}

McNieI, D. S. (2006). Meaning through narrative: A personal narrative discussing growing up with an alcoholic mother (Master's thesis). Available from ProQuest Dissertations and Theses database. (UMI No. 1434728)

in text citation: (Mc Niel, 2006)

\section{Doctoral dissertation, from an institutional database}

Adams, R. J. (1973). Building a foundation for evaluation of instruction in higher education and continuing education (Doctoral dissertation). Retrieved from http://www.ohiolink.edu/etd/

in text citation: (Adams, 1973) 


\section{Doctoral dissertation, from the web}

Bruckman, A. (1997). MOOSE Crossing: Construction, community, and learning in a networked virtual world for kids (Doctoral dissertation, Massachusetts Institute of Technology). Retrieved from http:/www-static. cc.gatech.edu/--asb/thesis/

in text citation: (Bruckman, 1997)

\section{Journal article with No DOI}

Bourkhis, K., and Nabi, M. S. (2013). Islamic and conventional banks' soundness during the 2007-2008 financial crisis. Journal Metrics, 22(2), 68-77.

in-text citation: (Bourkhis \& Nabi, 2013).

\section{Journal article with DOI}

Ichwan, M. (2012). The Local Politics Of Orthodoxy: The Majelis Ulama Indonesia in the Post-New Order Banten. Journal Of Indonesian Islam, 6(1), 166-194. doi:http://dx.doi.org/10.15642/JIIS.2012.6.1.166-194

In text citation : (Ichwan, 2012)

\section{Abstract as citation}

Hasan, N. (2012). Islamist Party, Electoral Politics And Da'wah Mobilization Among Youth : The Prosperous Justice Party (PKS) in Indonesia. Journal of Indonesian Islam, 6(1), 17-47. Abstract from http:// jiis.uinsby.ac.id/index.php/jiis/article/view/97

in text citation : (Hasan, 2012)

\section{Mass media article}

Sahal, Akhmad (2014, March 2). Kiai Sahal dan Realisme Fikih.Tempo Magazine, p. 120.

in text citation : (Sahal, 2014) 


\section{Research report}

Fisher, B. S., Cullen, F. T., \& Turner, M. G. (2000). The Sexual Victimization of College Women. Research Report.

in text citation : (Fisher, Cullen, Turner, 2000)

\section{Monograph}

Routray, Bibhu Prasad (2013), National Security Decision-Making in India (RSIS Monograph No. 27). Singapura: Rajaratnam School of International Studies.

in text citation : (Routray, 2013)

\section{Proceeding article}

Sudibyakto, Hizbaron, D.R., \& Jati, R (Ed.) (2009), Proceeding International Seminar Disaster Theory, Research and Policy. International seminar held by Sekolah Pascasarjana, Universitas Gajahmada, Yogyakarta, 8-9 Desember 2009.

in text citation : (sudibyakto and Jati, 2009)

\section{Paper conference/seminar/symposium}

Janutama, Herman Sinung (2011). "Kraton dan Hubungan Antar Agama." Paper presented in Seminar Kraton dan Panatagama held by Center for the Study of Islam and Social Transformation (CISForm), Yogyakarta, 17 November.

in text citation :(Janutama, 2011)

\section{Online article in web}

Shiva, (2006, February). Bioethics: A Third World Issue. Native-web. Diperoleh dari http://www.nativeweb.org/ pages/legal/shiva.html

in text citation : (Shiva, 2006) 


\section{Online research report}

Kessy, S. S. A., \& Urio, F M. (2006). The contribution of microfinance institutions to poverty reduction in Tanzania (Research Report No. 06.3). Retrieved from Research on Poverty Alleviation website: http://www. repoa.or.tz /documents_storage/Publications/Reports/06.3_Kessy_and_ Urio.pcif

in text citation : (kessy and urion, 2006)

\section{Holy book}

Qur an, $2(25)$

In text citation : (Q. al-Baqarah 2:25).

\section{Encyclopaedia}

Graycar, Adam (1992). Social Welfare Policy. Dalam Mary Hawkesworth dan Maurice Kogan (Ed.), Encyclopedia of Government and Politics (Vol. 1). London: Routledge.

in text citation : (Graycar, 1992)

\section{Interview}

Sultan Hamengkubuwono X (interview, 2011, April 19)

in text citation: (Hamengkubuwono, 2011)

\section{Documentary film}

Steijlen, Fridus (2008). A Day in the Life of Indonesia [documentary film, 58 minutes]. Leiden: KITLV Press.

in text citation : (Steijlen, 2008) 
Vol. 3 No. 1, January - April 2018 